\section{Znanstveni skup Demografija u Hrvatskoj: zbornik radova}

Zagreb: Ekonomski fakultet, 2014, 514 str.

DOI: 10.11567/met.30.2.7

Na znanstvenom skupu Demografija u Hrvatskoj povodom pedeset godina rada akademkinje Alice Wertheimer-Baletić, održanom 10. prosinca 2012. na Ekonomskom fakultetu Sveučilišta u Zagrebu, okupili su se znanstvenici iz više znanstvenih područja tematizirajući demografsku problematiku s posebnim naglaskom na $\mathrm{Hr}$ vatsku. Uz potrebu Katedre da izrazi akademsku zahvalnost profesorici Wertheimer-Baletić organiziranje ovakva interdisciplinarnog skupa ujedno je i veoma logičan događaj na znanstvenoj sceni jer su demografske teme ili, bolje rečeno, demografski problemi kojima je zahvaćen razvijeni svijet sve zastupljeniji u stručnoj i široj javnosti na početku 21. stoljeća. Znanstveni radovi izloženi na skupu publicirani su u zborniku koji obuhvaća 22 znanstvena rada (26 autora). Urednici zbornika članovi su Katedre za demografiju prof. dr. sc. Anđelko Akrap, doc. dr. sc. Ivan Čipin i dr. sc. Marin Strmota, a recenzenti su prof. dr. sc. Jakov Gelo i prof. emeritus Mladen Ante Friganović.

Autori su se u svojim radovima bavili različitim temama iz područja demografije. U uvodnom dijelu zbornika Anđelko Akrap razmatra znanstveni doprinos i impozantnu pedesetogodišnju znanstvenu i nastavnu djelatnost Alice Wertheimer-Baletić. Posebno su istaknuti znanstveni doprinosi pojedinim demografskim područjima, s naglaskom na one koji neprijeporno pokazuju da je Alica Wertheimer-Ba- letić utemeljiteljica suvremene demografije u Hrvatskoj kao znanstvene i nastavne discipline.

Prvi rad »Demografska posttranzicijska etapa u Zapadnoj Europi - obilježja i čimbenici (razdoblje od 1960. do 2010. godine)« napisala je Alica Wertheimer-Baletić, koja teorijski i demografsko-analitički obrađuje posttranzicijsku etapu razvoja stanovništva u izabranim zemljama Zapadne i Sjeverozapadne Europe. S obzirom na kompleksnost posttranzicijske razvojne etape akademkinja navodi njezina ključna demografska obilježja. U nastavku detaljno opisuje promjene u smjeru i intenzitetu kretanja nataliteta/fertiliteta u odabranim zemljama Zapadne Europe od 1960. do 2010. te objašnjava čimbenike smanjivanja nataliteta u tom razdoblju.

Anđelko Akrap u radu "Činitelji fertiliteta u Hrvatskoj: nekad i danas « daje pregled činitelja fertiliteta opisujući ih sustavno u dva demografskoanalitička razdoblja: od sredine 19 . do sredine 20. stoljeća i od sredine 20. stoljeća do danas. Autor ističe utjecaj specifičnih društvenih i gospodarskih prilika na fertilitetne intencije stanovništva pojedinih područja u Hrvatskoj u tim razdobljima.

U analizi niskog fertiliteta u Europi Ivan Čipin i Marin Strmota u radu »Druga demografska tranzicija u Hrvatskoj « pozivaju se na teoriju druge demografske tranzicije (DDT). Ističući teorijski koncept druge demografske tranzicije i njene pokazatelje, autori to podupiru citiranjem relevantne svjetske znanstvene literature i rezultatima anketnog istraživanja provedenog u Hrvatskoj koji pokazuju stavove vezane uz formiranje obitelji i ferti- 
litetno ponašanje. Ipak, zaključuju da $\mathrm{u}$ testiranju teorije DDT navedeni pokazatelji i provedeno istraživanje nisu dostatni bez budućih istraživanja longitudinalnoga karaktera.

»Rad izvan kuće, radno vrijeme i djeca « autorice Zdenke Damjanić bavi se istraživanjem stavova studentica Ekonomskog fakulteta u Zagrebu prema mjerama obiteljske politike i majčinstvu. Rezultati istraživanja pokazali su da studenticama nije toliko važna karijera koliko potpun i uspješan obiteljski život, a od mjera najvažnijima smatraju one koje uređuju rodiljni dopust, bolje vrtiće i fleksibilno radno vrijeme. I ovo je istraživanje pokazalo kako ključnu ulogu u mjerama obiteljske politike imaju pristup zapošljavanju žena i razvoj usluga za djecu i obitelj.

Uz već općepoznati dugotrajni nepovoljni demografski razvoj stanovništva Hrvatske Ivo Nejašmić fokusira se na demografske i društveno-gospodarske posljedice takva razvoja. U radu »Kamo ide Hrvatska? Buduće demografske promjene i neke njihove posljedice « daje pregled negativnih trendova poput daljnjeg smanjenja rodnosti, smanjenja školske populacije, smanjenja i starenja radnoga kontingenta i povećavanja troškova za mirovine, zdravstvenu zaštitu i socijalnu skrb. Ne baš optimistično, autor predviđa daljnje umnožavanje negativnih posljedica u gotovo svim područjima društvenog života.

"Jesu li i prije 18. stoljeća postojali procesi demografske tranzicije? « naslov je rada u kojem Nenad Vekarić istražuje mogućnost postojanja nekih drugih tranzicijskih procesa koji su se odvijali paralelno s općepoznatim procesom demografske tranzicije. Vo- deći se tom mišlju, analizira nekoliko demografskih pokazatelja (dob stupanja u brak, doživljena dob, ritam porođaja, brzina generacijske smjene) na uzorku od dvanaest hrvatskih župa te zaključuje kako je u predtranzicijskoj etapi razvoja stanovništva bilo nekoliko reverzibilnih tranzicijskih procesa. Iako oni nisu bili toliko snažni ni značajni kao proces demografske tranzicije, bili su relativno važni na manjim područjima.

Navodeći brojna teorijska i empirijska istraživanja provedena u Hrvatskoj, Stjepan Šterc i Monika Komušanac u radu "Strateška promišljanja hrvatskih demografa " pružaju posve pesimističnu sliku demografske budućnosti Hrvatske. Upozoravajući na demografske probleme koji ugrožavaju ukupni razvoj, opstanak i identitet Hrvatske, autori naglašavaju strateški potencijal stanovništva i ističu potrebu za nacionalnom strategijom razvoja stanovništva.

Janez Malačić i Jože Sambt u radu »Fertilitet u Sloveniji i Hrvatskoj u posljednjim desetljećima i jednostavno obnavljanje stanovništva" analiziraju kretanje fertiliteta u Hrvatskoj i Sloveniji opisujući metodološke nedostatke stope ukupnog fertiliteta. Autori su stručno, na primjeru samo jednog pokazatelja, upozorili na tehničku i analitičku složenost demografskih procesa. Upotrebom BongaartsFeeneyjeve metode, prilagođenom stopom ukupnog fertiliteta zaključuju kako je smanjenje fertiliteta ispod jednostavne reprodukcije nešto niže negoli je prikazano neprilagođenom, periodskom stopom ukupnog fertiliteta u posljednjim desetljećima demografskih istraživanja. Ipak, zaključuju kako ni nešto veća vrijednost stope 
ukupnog fertiliteta dobivene navedenom metodom ne poboljšava lošu fertilitetnu sliku Hrvatske i Slovenije.

Vlado Puljiz u radu »Demografski procesi i socijalna politika « razmatra utjecaj nepovoljnih suvremenih demografskih procesa na socijalnu politiku u europskim zemljama. Izdvaja tri ključna demografska procesa koja, kako kaže, proizvode socijalne probleme - starenje stanovništva, migracije stanovništva i promjene u strukturama i funkcijama obitelji. U radu se autor ograničava na starenje stanovništva upućujući na nekoliko aspekata toga globalnog demografskog procesa.

Služeći se rezultatima provedenog istraživanja, Pero Aračić u radu »Odnosni aspekt u kršćanskom identitetu « obrađuje fenomen ljudskog identiteta s posebnim naglaskom na religiozni/vjerski identitet upozoravajući na kompleksnost ljudskog identiteta i potrebu za interdisciplinarnim pristupom u njegovu proučavanju.

U opširnu radu »Demografska istraživanja $\mathrm{u}$ sjeverozapadnoj $\mathrm{Hr}$ vatskoj u ozračju metodoloških dostignuća Alice Wertheimer-Baletić« značajni prilog suvremenoj ekodemografiji dao je Dragutin Feletar istaknuvši utjecaj akademkinje čiji je znanstveni rad pomogao $\mathrm{u}$ povezivanju prirodno-geografskih značajki i promjena u distribuciji stanovništva.

U radu »Etnologija/kulturna antropologija i demografija: susretišta i razilaženja« Jasna Čapo ambivalentno pristupa povezivanju demografije i etnologije/kulturne antropologije upućujući s jedne strane na tematsku bliskost tih dviju disciplina, a s druge na njihovu metodološku i epistemološku različitost. Autorica prikazuje kom- plementarnost kvantitativne građe i demografske analize s etnološkim pristupom istraživanju, ali posebni naglasak stavlja na metodološko razilaženje, čiji uzrok vidi u nedovoljnom dijalogu demografâ i etnologâ.

Teološki pristup demografskoj problematici u radu »Utječe li vrijednosna (dez)orijentacija na demografska kretanja u Hrvatskoj? « donosi Stjepan Baloban ističući važnost vjerskoreligijskog čimbenika u znanstvenom tumačenju. Autor se pita predstavljaju li vrednote poticaj ili prepreku razvoju hrvatskog stanovništva. Empirijsko istraživanje europskih vrednota pokazalo je da Hrvati još uvijek visoko cijene brak i obitelj, a temeljne vrednote skriveni su kapital hrvatskog naroda, zaključuje Baloban.

»Prisilne (ratne) migracije kao čimbenik demografskih promjena u Hrvatskoj (1991. - 2011.)« naslov je rada Dražena Živića. Autor procjenjuje negativnu migracijsku bilancu između "ratnog " popisa 1991. i posljednjeg 2011., proizišlu iz niza društvenih, gospodarskih i demografskih posljedica Domovinskog rata. Osnovni cilj i svrha rada bili su procijeniti bilancu prisilnih migracija u navedenome dvadesetogodišnjem razdoblju. Usprkos metodološkim poteškoćama vezanim uz dostupnost i vjerodostojnost statističkih izvora o prisilnim (ratnim) migracijama autor detaljno opisuje migracijske tokove $\mathrm{u}$ ratnom i poratnom razdoblju i potvrđuje utjecaj prisilnih migracija na sve sastavnice demografske dinamike i strukture stanovništva u Hrvatskoj.

Božena Vranješ-Šoljan u radu »Hrvatska na početku nagodbenog razdoblja: u odrazu popisa stanovništva 1869.« opisuje povijesne događaje koji 
su obilježili drugu polovinu 19. stoljeća te populacijske promjene utvrđene popisom stanovništva 1869. Društveni, gospodarski i politički uvjeti u Habsburškoj Monarhiji bili su u direktnoj sprezi s razvojem stanovništva i njegovim strukturama u Hrvatskoj i Slavoniji. Tadašnji razvoj stanovništva karakterizirao je tradicijski način života s početnim elementima demografske preobrazbe. Kako zaključuje autorica, kao rezultanta visokih (predtranzicijskih) stopa nataliteta i mortaliteta, demografska situacija šezdesetih godina 19. stoljeća bila je statična i kao takva pogodovala je očuvanju postojećih demografskih struktura.

»Demografsko stanje na Jadranskim otocima na prijelazu u 21. stoljeće« analizira Ivan Lajić. Autor u prvom redu zaključuje kako je prema posljednjem popisu stanovništva 2011. u usporedbi sa prijašnjim popisima (1981., 1991. i 2001.) došlo do povećanja udjela otočnog stanovništva u ukupnom stanovništvu Hrvatske. Usporedbom dinamike ukupnoga kretanja stanovništva grupiranog $\mathrm{u}$ otočne skupine razvidno je kako od svih skupina samo južnodalmatinski otoci bilježe negativne trendove. No potrebno je naglasiti kako se to stanje bitno mijenja ako se analiza spusti niže, na razinu pojedinačnih otoka, kada veliki broj otoka pokazuje trendove depopulacije (najbolju situaciju pokazuju tzv. premošteni otoci). Također, realnija (loša) demografska slika jadranskih otoka prikazana je prirodnim kretanjem stanovništva.

Na interakciju tržišta rada i demografskih promjena osvrnuo se Predrag Bejaković. U radu »Demografsko starenje i mjere za zadržavanje starijih osoba u svijetu rada« autor analizi- ra stanje i odrednice radne aktivnosti starijih osoba, ali i opisuje moguće mjere za zadržavanje starijih osoba u radnoj snazi. Značajni dio rada čini sažeti prikaz mirovinskih prava i reformi u zemljama članicama EU-a.

Vjerski sastav stanovništva od početka druge polovine 20. stoljeća do danas prikazao je Nenad Pokos u radu »Promjene vjerskog sastava stanovništva Hrvatske od 1953. - 2011. godine«. Autor skreće pozornost na problem metodološke naravi u praćenju vjerskog sastava stanovništva na našem području s obzirom na to da od popisa 1953. do popisa 1991. pitanje o vjerskoj pripadnosti nije postavljano.

Snježana Mrđen u radu »Glavne odrednice ukupnog kretanja stanovništva Hrvatske, 1991. - 2001. i 2001. - 2011." analizira udio komponenata prirodnoga i mehaničkoga kretanja u ukupnom stanovništvu tijekom dva posljednja međupopisna razdoblja u Hrvatskoj. Posebni naglasak stavlja na analizu demografskoga kretanja na nižim teritorijalnim razinama. Iako je metodološki teško usporediti tri posljednja popisa u Hrvatskoj, autorica zaključuje kako je posljednje međupopisno razdoblje zabilježilo rast broja stanovnika. Taj porast objašnjava pozitivnim migracijskim saldom na prostorima koji su u prethodnome (ratnom i poratnom) razdoblju (1991. 2001.) bilježili značajnije emigracijske tokove.

Detaljnu analizu kretanja ukupnog broja stanovnika srednjodalmatinskih otoka od 1857. do 2011. daju Mladen Smoljanović i Ankica Smoljanović u radu »Temeljne značajke stanovništva srednjodalmatinskih otoka popisne 2011. godine«. Brojnim grafičkim i tabličnim prilozima pokazuju vrlo 
nepovoljne demografske trendove na hrvatskim otocima. Jasno se vidi starenje svih kontingenata i sužavanje baze, odnosno smanjivanje ili potpuni izostanak rađanja na otocima.

Nada Antić govori o »Povezanosti demografije s drugim društvenim, posebno ekonomskim znanostima« navodeći glavna područja društvenih istraživanja u kojima su demografske pojave i njihove implikacije neizbježni dio tematike. U uvjetima značajnih demografskih promjena autorica opravdano skreće pozornost na zanemarena demografska pitanja i potrebu stvaranja svojevrsne nacionalne institucije za demografska istraživanja.

U zadnjem radu zbornika »Dnevna cirkulacija (migracija) stanovništva u srednjim gradovima Hrvatske« Ivo Turk analizira pokretljivost stanovništva u Hrvatskoj, naročito onu cikličkoga i kratkotrajnoga karaktera. Autor obrađuje dnevne cirkulacije kao relevantni pokazatelj interakcije gradova i okolice, odnosno funkcionalne (ne) ovisnosti pojedinog naselja ( $u$ radu su obrađeni srednji gradovi, njih 29).
Cilj je istraživanja ostvaren i autor zaključuje kako su neki gradovi pokazali funkcionalnu ovisnost, a drugi neovisnost o funkcijama većih gradova u okolici. Nedostatak je rada u činjenici da podaci o dnevnoj cirkulaciji za 2011. godinu nisu bili objavljeni u vrijeme pisanja rada, pa je autor opisao stanje iz 2001.

U nastojanju da što bolje opišu kompleksne demografske promjene kojima je zahvaćeno hrvatsko društvo, $\mathrm{u}$ radovima autori iznose brojne spoznaje iz matičnih znanstvenih područja, ali i uključuju, uvažavaju i isprepleću spoznaje drugih znanstvenih područja. Ovaj je zbornik skup važnih interdisciplinarnih istraživanja, predavanja i mišljenja o demografskim, gospodarskim, političkim, vjerskim i sociokulturnim čimbenicima razvoja stanovništva Hrvatske. Zbornik radova sa znanstvenog skupa Demografija u Hrvatskoj znanstveno je relevantan, aktualan i nadasve koristan za razumijevanje objektivne demografske stvarnosti u Hrvatskoj.

Marin Strmota

Ekonomski fakultet Sveučilišta u Zagrebu, Zagreb 